\title{
Age diversity and the aging librarian in academic libraries in South Africa ${ }^{\prime}$
}

\author{
Sophie van der Walt ${ }^{2}$, Tanya du Plessis ${ }^{3}$ \\ Centre for Information and Knowledge Management, University of Johannesburg \\ vdwalsc@unisa.ac.za; tduplessis@uj.ac.za
}

\begin{abstract}
Received: 23 June 2010
Accepted: I July 2010

The focus of this article is to illustrate the current age distribution of academic librarians in South Africa and to determine the need for age diversity management in academic libraries. Firstly, a literature review provides a brief overview of recent changes to the higher education landscape in South Africa and the importance of diversity awareness. Secondly, the issue of age diversity in the workplace is explored, followed by a discussion of the age demography of librarians, so raising the important issue this paper seeks to investigate, namely, the current age demography of South African academic librarians. A mixed-method research approach was decided upon and specifically the sequential exploratory design as it studies the unknown relationships between different generations of librarians at work within five of the academic libraries from the Gauteng and Environs Library and Information Consortium (GAELIC). The results showed that most of the middle and senior level library management positions are currently filled by those retiring in the next 15-20 years and that the planning and training of new middle and top management staff members must form part of succession planning policies in order to avoid a leadership vacuum.
\end{abstract}

Keywords: Generational diversity; generational awareness; academic libraries; library management; succession planning

\section{Introduction}

To date a great deal of research has been conducted on diversity management in South Africa (Dombai \& Verwey 1999; Greybe \& Uys 200 I; Human 2005; Cilliers \& Smit 2006). However, very little of this research focuses on the age diversity of information professionals, and specifically that of academic librarians. From the literature review it is clear that most of the studies regarding age diversity within libraries were directed at understanding the age differences between library patrons and library staff members. This study explores the different generations of co-workers in South African academic information services in order to develop an awareness of their age diversity.

In order to develop an awareness of the age diversity between co-workers, the research question posed in this article is stated as follows: What is the current age distribution of academic librarians in South Africa and what need exists for age diversity management in academic libraries?

To address this problem sufficiently the article will begin by providing a brief overview of recent changes to the higher education landscape in South Africa, specifically with regard to diversity. Secondly, the article introduces the issue of age diversity in the workplace together with an overview of age diversity in the academic library arena. This will be followed by a discussion of the age demography of academic librarians in Australia, Canada, the USA and UK, raising the important issue this article seeks to investigate, namely the current age demography of South African academic librarians. However, before the issue of age diversity can be discussed, it is important to understand the concept of diversity within the workplace.

\section{Diversity in the South African workplace}

During the last century, the workplace has changed from an analogous environment to one that is rich with diversity not only in terms of language, but also in terms of culture, race, ethnicity, age, gender, sexual orientation and differently-abled people. South Africa is no exception, but Dombai and Verwey (1999:105) and Human (2005) point out that representation of this diversity has been missing within most South African organisations. Nonetheless, this situation is beginning to change and the social and political changes that have occurred in this country are compelling organisations to incorporate workforce diversity (Dombai \& Verwey 1999: 126). This is also true of the higher education institutions (HEI), as is evident from the changes in the HEl landscape in South Africa.

I. This article is based on the Masters dissertation submitted to the Department of Information and Knowledge Management, University of Johannesburg. We wish to acknowledge the South African Library and Information Trust for making a research grant available in support of the research conducted in fulfilment of the degree MPhil (Information Management) at the University of Johannesburg in 2010.

2. Sophie van der Walt is a librarian at the University of South Africa (Muckleneuk Branch), Pretoria, South Africa.

3. Correspondence author Tanya du Plessis (D Litt et Phil) is a senior lecturer in the Department of Information and Knowledge Management, University of Johannesburg, Auckland Park, South Africa. 
2.1 Changes to the higher education landscape in South Africa

Addressing the issue of workforce diversity requires a brief overview of the social and political changes impacting on South African organisations and more specifically the South African HEl landscape. HEI have undergone tremendous and tumultuous changes in the past decade and these changes have influenced diversity both within these institutions and within their academic libraries.

Under the apartheid regime there were separate tertiary institutions for groups categorised as Coloureds, Indians, Blacks and Whites. These institutions consisted of technical colleges or technikons and universities (Barnard 2008:14; Kagan 2003:I). The standards of the historically white institutions were always perceived to be superior to those of the historically black institutions, and this perception had some foundation in the harsh reality that government gave these institutions less funding, funds were mismanaged, the curricula were more limited than those of historically white institutions and studies were prone to disruption owing to political protests combined with protests at the lack of mother tongue lectures and study material (Barnard 2008:14).

The transformation envisaged by the Government of National Unity was instigated by the creation of the National Commission on Higher Education (NCHE 1996), the adoption of the Higher Education Act 10I of 1997, the third Education White Paper of $200 \mathrm{I}$ and the creation of the National Plan for Higher Education (NPHE) in 200I (Nkoane 2006:244). The Education White Paper of 1997 was followed by a five-year process of consultation between the Council on Higher Education (CHE), the Minister of Education and the various management bodies of the HEl of South Africa. This process resulted in the NPHE where mergers were seen as a way to create new institutional forms (Hall, Symes \& Luescher 2004:32). Then, in 2002, the Minister of Education revealed the extent of the planned transformation which included the proposal to reduce the total number of HEl from 36 to 21 institutions. This would be accomplished by a number of mergers and incorporations (Nel \& Stumpf 2007:2), notwithstanding certain cases of unwillingness. Goldman and Van Tonder (2006: I48) describe how the unwillingness of the institutions to be merged added to the complexity of this national venture. The partners of the pre-merger HEl arena in South Africa consisted of 21 universities and 17 technikons (Sayed 2000:475). After the mergers, the current and remaining South African institutions of higher education comprise II universities, six universities of technology, six comprehensive universities and two national institutes (Nkoane 2006:246).

As the HEl in South Africa were compelled to transform and merge, the changes to their organisational structures as well as to the demographics of their student and staff profiles also reflected in their merged academic libraries. Along with their parent institutions, academic information service providers were confronted with the same pressures and demands not only to change their structures, but also to encourage and incorporate a more diverse staff complement.

Dewey and Keally (2008:622) point out that HEl are increasingly emphasising that diversity is core to the duty of learning, the creation of knowledge, community engagement, and institutional social responsibility. Adding to the complexity of the academic library landscape are the rapid changes in technology, a sharp rise in student and staff numbers and the increased demands this influx entails (Raubenheimer \& Müller 2006:232-248). According to the South African Yearbook (2008/2009:181), academic information service providers are under particular pressure from the redistribution of educational resources, rising prices and declining student numbers. Other pressures include staff shortages, and the need for capacity building and staff development (Thomas \& Fourie 2006:436). These factors all place academic libraries under tremendous pressure to respond and thrive on change and to incorporate diversity even more. Notably, Bopape (2005:64-65) lists diversity as one of the main challenges for academic libraries within the South African context.

\subsection{Diversity within the South African context}

In the South African framework diversity can be seen as a combination between individuals and groups that have discernible social identities (Cilliers \& Smit 2006:6). Human (2005:3-4) agrees with this and states that diversity entails more than issues of race or gender and that diversity management is the basis for effective organisational behaviour. Diversity management is also defined as a management process where 'leaders mobilise and enact a shared system of meaning by articulating and defining what has remained implicit and by providing followers with a means of making sense of their experiences' (Dombai \& Verwey 1999:106). Others define it as a method of creating both international and intranational situations that incorporate differing standpoints, attitudes and understandings to realise the full abilities of the employees and the organisation (Greybe \& Uys 200I:186).

To realise the full abilities of its people, the South African government is taking an active interest in the diversity within organisations by passing legislation and regulations to promote under-represented groups as instructed by the Constitution of the Republic of South Africa, 1996. Examples of such legislation include the Broad-Based Black Economic Empowerment Act 53 of 2003, the Broad-Based Black Economic Empowerment Bill, the Skills Development Act 97 of 1998, affirmative action, the Promotion of Equality and Prevention of Unfair Discrimination Act 4 of 2000 and the Black 
Economic Empowerment Charter (Human 2005; Dombai \& Verwey 1999). These examples together with the more extensive list provided by Bopape (2005:64-65) are aimed at equal opportunities, justness and transformation.

While these legislative measures rightly work to correct the outcomes of past inequities, their focus is predominantly on characteristics of diversity such as gender and race; and less on age as a diversity characteristic. The Constitution and legislation tackle age discrimination but do not expressly mention or promote age diversity, which raises the need for research on this phenomenon, so that organisations can more fully investigate the role of age diversity management in their workplace and thereby reap the benefits of a more complete diversity.

Diversity is not simply a legal imperative; rather it equally makes business sense and brings many benefits to the organisation and its clients, patrons or consumer base. Bell (2007:5) argues that diversity has benefits for everyone in an organisation and suggests managers should implement a thorough managerial process to enable an environment that is suitable for all employees. Kreitz (2008:105) agrees and states that if diversity is managed successfully it can enhance organisational performance and customer services, specifically in the areas of problem solving, creativeness, innovation and flexibility. Aghazadeh (2004:523) cautions, however, that diversity should not be implemented to simply pay lip service to legal requirements such as affirmative action quotas, but should be deeply linked to business goals.

Diversity, specifically workplace diversity, poses certain challenges which require special consideration. According to Aghazadeh (2004:528), staff from diverse groups may feel threatened when working with each other. In response to the need for diversity awareness, organisations may experience increased training costs invested in, for example, cultural integration seminars and other diversity related training courses for employees. Organisations may find that claims of reverse discrimination increase and that an increase in conflict leads to absenteeism and higher staff turnover. Furthermore, Aghazadeh (2004:528) warns that if diversity management is not correctly implemented and reviewed regularly it leads to employee dissatisfaction and loss of productivity.

In addition to lower productivity, an organisation that lacks a true appreciation of diversity will experience the negative impacts of high staff turnover and the associated costs of replacing staff, no return on the investment made in training, a compromised brand and employer image, unrealised market access, lack of market awareness, and sometimes legal action against the organisation (Greer \& Virick 2008:353). In the last instance, litigation usually stems from latent institutional racism and other forms of discrimination (Clements \& Jones 2002:6).

With diversity encompassing so many different aspects of an individual (for example, race, ethnicity, sexual orientation, mobility and age) the focus of this article is only on one aspect, namely that of age and specifically age diversity in the workplace.

\section{Age diversity in the workplace}

As mentioned previously, age is rarely discussed as a focal point of diversity in South Africa, the emphasis being more on gender and race. Although this is understandable considering South Africa's turbulent history, the fact remains that II.84\% of the population is estimated to be 50 years or over, according to StatsSA (2007). Effectively these people will be retiring in 10-15 years' time. This means that their organisations should start planning and focusing on who will be replacing them. In order to achieve this focus, organisations must firstly understand and appreciate the complexity of age diversity.

Age is a somewhat unique aspect of diversity as it is not as permanent as race or gender. In this regard Bell (2007:3/2) fittingly asks: 'at what age do positive perceptions about younger workers (e.g. trainable, energetic) cease and perceptions shift to negative (e.g. too old to learn, set in ways)?' thereby emphasising that it is quite hard to pinpoint 'old enough' or 'too old'. Age is also a very visible aspect of diversity (as opposed to sexual orientation or marital status) and both Awbrey (2006:8) and Ayoka and Härtel (2006:348) make the case that visible forms of diversity are more likely to bring out stereotypes and discrimination.

Another organisational problem created by age occurs when a younger, inexperienced supervisor is put in charge of older, experienced employees. This has social status implications as 'subordinates who are older than their supervisors may experience status incongruence' (Perry, Kulik \& Zhou 1999:343). Also, older subordinates in the study by Perry, Kulik and Zhou (1999) tended to respond negatively when they perceived that their supervisors did not have the capacity to lead. Such perceptions affect workplace cohesion.

In terms of cohesion, Dinwoodie (2005:4) points out that the social categorisation approach to diversity assumes that individuals identify with one another due to their similarities, and the more similarities that exist, the higher the degree of cohesion and commitment among them. Desmette and Gaillard (2008:170) agree and point out that social or group membership forms part of each individual's self-definition and the strength of this identification with a group will influence their interaction with individuals from other groups as well as their work performance.

SA JnI Libs \& Info Sci 2010, 76(I) 
The above-mentioned social categorisation approach to diversity and the social membership of employees can affect work performance either positively or negatively. In organisations where there is a lack of sensitivity to age diversity, social identity conflict may occur and conflict can break out between different groups leading to a loss in work performance (Dinwoodie 2005:4; De Ferreire Kemp 2007:42). Stereotypes also have a negative impact on work performance as older employees may resist accepting challenging projects or become unmotivated (Maurer et al., 2008:409).

Stereotyping can also influence individuals' views with regard to the social membership of others. Negative stereotypes regarding older workers include that they have ill health, do not cope well with change, have higher levels of company loyalty, have better interpersonal skills, and are harder working and better at teamwork (Parry \& Tyson 2009:472). Stereotypes regarding younger workers include that they have greater absenteeism and job-related accidents (Parry \& Tyson 2009:473). Focusing too much on the internal characteristics of diversity within an organisation will result in cohesive social groups breaking up into dissimilar sub-groups and lead to a decline in an organisation's performance (De Ferreire Kemp 2007:42). Organisational performance is influenced by employee job satisfaction. As pointed out by Moyes, Williams and Koch (2006:537), there is a correlation between job satisfaction and employee turnover, arguing that job satisfaction attributes are age-related. Amending negative perceptions regarding certain jobs may therefore lead to an increase in work performance and a decrease in employee turnover.

From the literature it is clear that organisations have a responsibility to develop and implement policies to not only encourage age diversity, but also to create an organisational identity. Academic libraries are no exception to this, which consequently requires an investigation of age diversity in academic libraries.

\section{Age diversity in academic libraries}

Arguments for diversity in academic libraries include that students and academic staff prefer to interact with library staff they can identify with. Libraries have a responsibility not only to assist the community to understand and succeed within a multicultural society, but also to create and manage a diverse workforce that is sensitive to differences and respects pluralism (Royse, Conner \& Miller 2006:23).

Academic libraries that attract and retain a diverse workforce incur a number of benefits, including enhanced customer service and stronger support for the university's diversity strategy. This can be achieved by providing the diverse student population with librarians from under-represented groups and by building multicultural collections and services that representatively support and enrich the diversity dialogue and academic output (Dewey \& Keally 2008:623; Kreitz 2008:105). Saw and Todd (2007:3) argue that the main issues in academic libraries are the selection criteria for staff appointments, identifying the next generation of staff and customers, new technology and an aging and inter-generational workforce. However, the increasingly high staff turnover identified by researchers such as Strayer (2007), Kreitz (2008), and Mosley and Kaspar (2008), is cause for concern.

If academic libraries are to thrive in a diverse environment, specific approaches to retain and attract staff have to be found. For academic libraries to recognise the need to attract staff and implement successful succession policies, it is important to delineate the age profile of staff as a starting point. Academic libraries can only encourage a diverse, and specifically an age diverse staff complement, if they are aware of the age profile of their specific organisation. Dewey and Keally (2008:623) agree with Brindley (2006:292) and maintain that advancing a diverse academic information service is to be achieved only by recruiting bright and talented new librarians who are able to navigate their way through the world of information as they understand 'the need to connect to people in their chosen space and to ensure that scholarship is accessible through these spaces' (Dewey \& Keally 2008:623-624). Regrettably, few academic libraries recognise this need to recruit new staff members or implement a succession planning policy (Nixon 2008:250).

The important question posed in this study, and supported by Nixon (2008:25I), is that perhaps South African academic libraries have failed to understand the immediacy of the need for succession planning because, in the shortterm, they do not yet face the same shortages of new qualified staff as corporate organisations, but also of leaders within their own organisations. But is this true? To ascertain if there is a staff shortage in academic libraries in South Africa it is necessary to determine what the age profile within South Africa is, as well as the age profile of South African academic libraries, and to compare it to similar academic information service providers elsewhere in the world.

\section{Age demography of academic librarians of countries world-wide}

In South Africa, $10.7 \%$ of the total population is aged 50 years and older and will be retiring in $10-15$ years time (Datamonitor 2009; StatsSA 2007). By contrast, in the United States of America and Australia 17.8\% of the population is aged 50 years and older, while Canada can expect $18.9 \%$ of their population to start retiring in $10-15$ years time 
(Datamonitor 2009). The above percentages are in sharp contrast to the library profession and disprove Nixon's premise that these organisations do not face staff shortages.

According to the United States Association of Research Libraries (ARL), 67\% of ARL librarians are expected to retire between 2000 and 2020, with the largest percentage (27\%) retiring after 2010 (Wilder 1996:385). Lynch, Tordella and Godfrey (2005:28) confirmed Wilder's prediction and state that 45\% of ARL librarians will be aged 65 years by 2010 due to what they describe as the early wave of Baby Boomers reaching retirement age.

This same trend is reflected in Australia, where the Federal Department of Employment statistics for 2004 reflected that $52 \%$ of librarians are older than 45 years, with $20 \%$ being over 55 years of age (McCarthy 2005:42). Again this wave of retiring librarians is linked to the Baby Boomer generation reaching retirement age. This is probably due to the fact that they have accounted for the generational grouping most active in the workforce (McCarthy 2005:42).

In a more recent neXus survey conducted in 2008 by the Australian Library and Information Association (ALIA), it was found that $16.8 \%$ of all library staff are aged 56 years and over, while $34.1 \%$ of librarians are over 45 years old. The inference is that $50.9 \%$ of all library staff in Australia will be retiring within the next 15-20 years (Hallam 2008: I5). This means that the average age for an Australian librarian is 47 years, while the average age for the whole workforce is 39 years (Nash 2008: I I5).

When focusing on the academic library and information sector, commonly referred to as LIS in Australia, the figures reflect the same trend, with $17.2 \%$ of LIS staff retiring in 10 years time and $49.5 \%$ retiring in the next $15-20$ years (Hallam 2008:15). These statistics are also mirrored in the 2005 findings of the Australian Association for Research in Education (AARE) that indicate that $60 \%$ of academic staff engaged in education are more than 50 years old with $45 \%$ of all academic staff aged 50 years and older, and thus eligible for retirement in 15 years' time (Sayers 2007:477).

The situation is similar in Canada where, after 2006, twice the number of librarians will turn 65 than in the previous ten years (Canadian Library 2003:5). A follow-up study conducted two years later found that $25 \%$ of librarians were 55 years of age and older. This is more than double the national average where only $11 \%$ of employees are over 55 years of age (Canadian Library 2005:59). This trend is especially worrying as many of the employees who will retire in the next 10 15 years currently hold management and senior level positions.

In an effort to determine how the South African academic library sector compares to global trends in this regard a comprehensive literature search did not reveal related research results, statistics or other data covering this issue. The literature search did reveal that, while numerous studies have been undertaken to investigate different generations as patrons of libraries, very few focused on the different generations of librarians as co-workers.

To illustrate the above statistics, Figure I compares the percentage of the total population retiring in the next 10 - I5 years with the percentage of librarians retiring. Figure I was populated with data from the following sources: Datamonitor (2009), Hallam (2008: I5), Canadian Library (2005:59) and Wilder (1996:385).

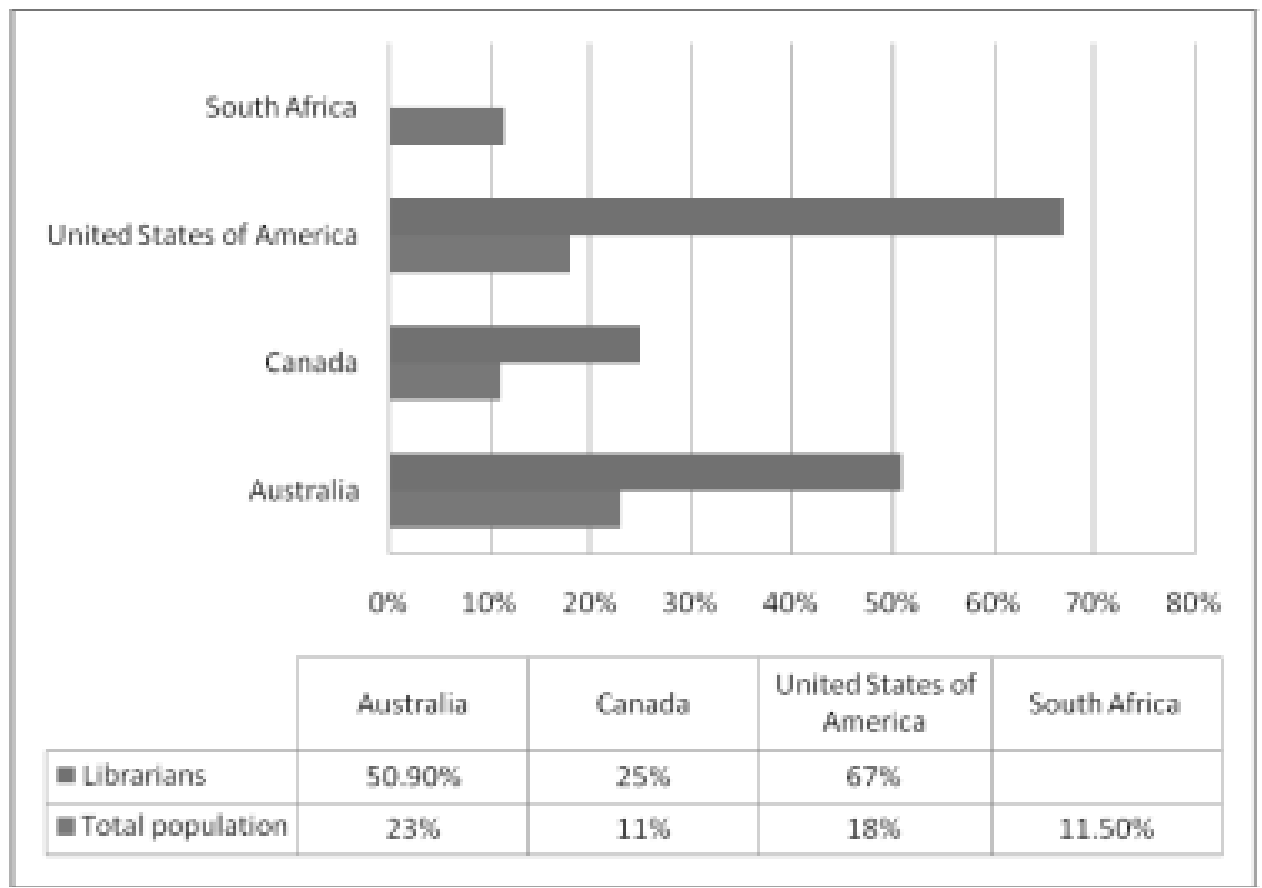

Figure 1 Total population retiring versus librarians retiring per country 
Figure I above clearly indicates the need for demographic data concerning the library sector. This need is also reflected in the South African National Council for the Library and Information Services draft Library and Information Services Transformation Charter, currently under discussion (NCLIS 2008). The Charter aims, amongst other things, to investigate the employment and expenditure trends of staff in the LIS environment and identified certain challenges for this investigation. One of the challenges mentioned in the draft Charter pertaining to employment trends of qualified librarians is the ageing workforce. The Charter states that 'the sector has not been in a position to collect baseline data and it is therefore necessary to establish the average age of qualified librarians; planning and training for new middle and top-management positions for succession planning' (NCLIS 2008: 18).

As stated above, the main issue this study aims to shed light on is the current age distribution of academic librarians in South Africa, seeking an answer to the following research question: What is the current age distribution of academic librarians in South Africa and what need exists for age diversity management in academic libraries?

\section{Methodology}

In line with the recommendations of Ngulube, Mokwatlo and Ndwandwe (2009:1I4-II5), the research approach followed in this study was that of a mixed-method research design. In order to achieve the research objective the sequential exploratory design was decided upon as it studies the unknown relationships between different generations of librarians at work within five academic libraries. It then generalises the findings to the population of academic librarians in South Africa.

In ascertaining how the South African academic library sector compares to global retiring trends, a comprehensive literature review was done with reference to age diversity and generational perspectives regarding work. As generational perspectives fall outside the scope of this article, it is covered here; however Van der Walt (2010:66-129) provides a detailed discussion on diverse generational perspectives relevant to South African academic libraries. The literature review was followed by an empirical research element characterised by a quantitative design. The data collection instrument consisted of a questionnaire, which was piloted and scrutinised by the University of Johannesburg Statistics Consultation Service (StatCon) before it was distributed to academic libraries of selected higher education institutions in South Africa.

In this study, the sample consists of librarians within the Gauteng and Environs Library Consortium (GAELIC). The survey excluded universities of technology, national research institutes, and other South Africa academic information service providers. The participating GAELIC libraries were limited to the five academic libraries situated in and near Gauteng, and included the North-West University (NWU); University of Johannesburg (UJ); University of the Witwatersrand (WITS); University of South Africa (Unisa); and the University of Pretoria (UP).

The main criterion for participation was identified as the following: participants in the survey have to be full-time permanent or contract librarians and this therefore excluded administrative staff and student library assistants. This measure was taken to ensure the sample included only professional librarians.

The survey used in the study can be described as a self-administered, small-scale, cross-sectional, descriptive and quantitative survey, based on the individual librarian as the unit of analysis. 'Self-administered survey' indicates the manner in which the data was collected and indicates that the researcher did not meet with any of the respondents, individually or in a group (Punch 2003:40). 'Small-scale' means that due to time and budget constraints, it was not possible to incorporate all the academic information service providers in South Africa into the sample, and hence a sample from the GAELIC group was used. 'Cross-sectional' refers to the fact that the survey collected data from respondents at only one point in time (Punch 2003:3). 'Descriptive' indicates the descriptive nature of the survey as it does not attempt to discuss the causes of variables, but only the relationship between them (Maree 2007:255). 'Quantitative' means that the researcher tested the relationship between variables using numerical data (Maree 2007:255). The 'individual librarian' as the unit of analysis indicates that the aim of the research is to investigate how librarians of different ages contrast or agree with the different variables tested and to show how the individual differences are related across all the variables (Punch 2003:3).

The survey focused on the different generations' attitudes with regard to their view on work, work performance and co-worker relationships as reported in Van der Walt (2010:157-191). The questionnaire was divided into three types of questions: Biographical data; close-ended questions, including list questions, multiple choice questions, filter questions and ranking questions. Some open-ended questions were included in line with the study's mixed-method research design. The questions were divided into two broad sections, namely, one section containing general information questions designed to garner demographic data; and the other section divided into six subsections that covered participants' views on work values and leadership, work-life balance, work performance, rewards and retirement. Of particular interest to this article are the results from the first section which collected data on the age of respondents.

SA JnI Libs \& Info Sci 2010, 76(I) 
The survey was distributed electronically and made available online to research participants for a period of two weeks. First, a pilot study was conducted to test the validity and reliability of the questions and response categories as well as the response rate that might be expected. The pilot questionnaire was sent out to librarians currently working within the abovementioned GAELIC libraries. Based on the suggestions of the participants, and on the results of the pilot, several of the questions were adapted.

The survey was then made available to 752 staff members at the participating libraries and a total of 145 responses were captured by StatCon which translates into a response rate of $(n) 19.28 \%$. A possible reason for the low response rate is that, except for the reminder email that was sent to the Library Directors as suggested by Andrews, Nonnecke and Preece (2003:192), no further reminder emails were sent out prior to the closure of the survey as suggested by Kaplowitz, Hadlock and Levine (2004:100).

Nonetheless, the survey rendered sufficient results and may be of even more value in further longitudinal studies aimed at investigating the age demography of academic librarians in South Africa.

\section{Results and discussion}

Earlier in this article it was argued that few academic libraries recognise the need to recruit new staff members or implement a succession planning policy. The possible explanation put forward was that perhaps academic libraries do not see the need for succession planning, as they do not yet face shortages not only of qualified new staff but also of leaders within their own organisations.

To test this possibility, Figure I compared the percentages of the population retiring of Australia, Canada, the United States of America and South Africa versus the percentage of librarians retiring in those countries. But Figure 2 notably did not include a value for the percentage of librarians retiring in South Africa as no data was available. With the results of the current survey it is now possible to not only determine the age distribution of librarians working in academic libraries, as reflected in Figure 2, but also populate Figure I with the missing values and determine whether or not South African academic libraries face a future shortage of academic librarians.

Figure 2 reflects the age distribution of the sample as defined by the age groupings used by Statistics South Africa (StatsSA), with the highest frequency percentage being in the age category $50-54$ years $(20.7 \%)$, followed by the age categories 55-59 years (17.1\%), and 45-49 years (14.3\%). The age categories with the lowest frequency percentage were $30-34$ years $(6.4 \%)$ and $24-29$ years $(2.9 \%)$. The full age distribution of participants in this study, namely, $24-60+$ years, is illustrated in Figure 2.

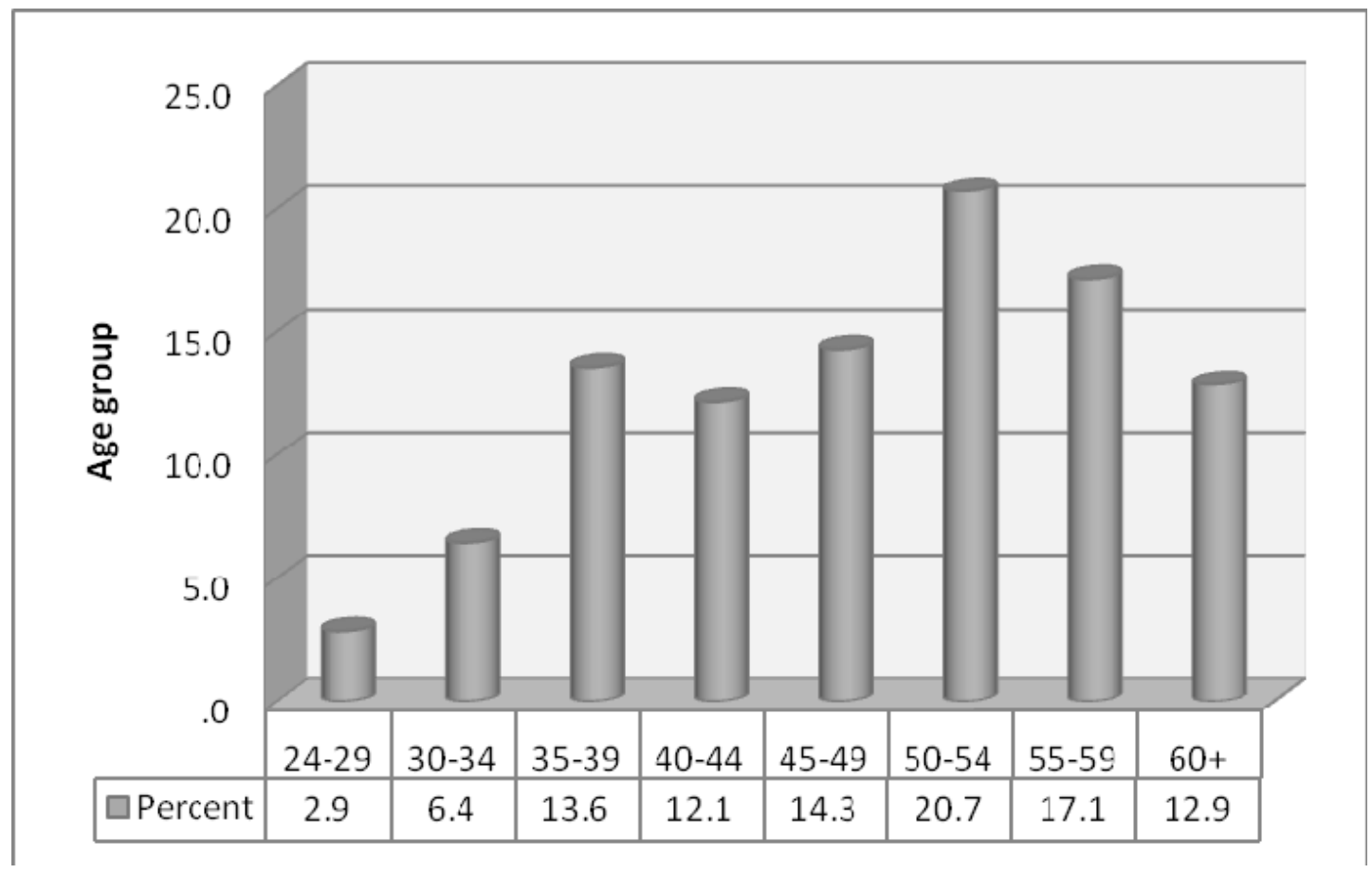

Figure 2 Age distribution of survey respondents according to StatsSA groupings

From the above results (Figure 2), it is evident that the largest section, namely $52.1 \%$ of respondents, falls in the age bracket of 45 to 59 years of age. Adding to this percentage, $12.9 \%$ of respondents are 60 years or older, which means 
that the majority, namely $65 \%$ of respondents, have reached the $45+$ age group. It is also evident that no respondents younger than 21 years of age participated in the survey.

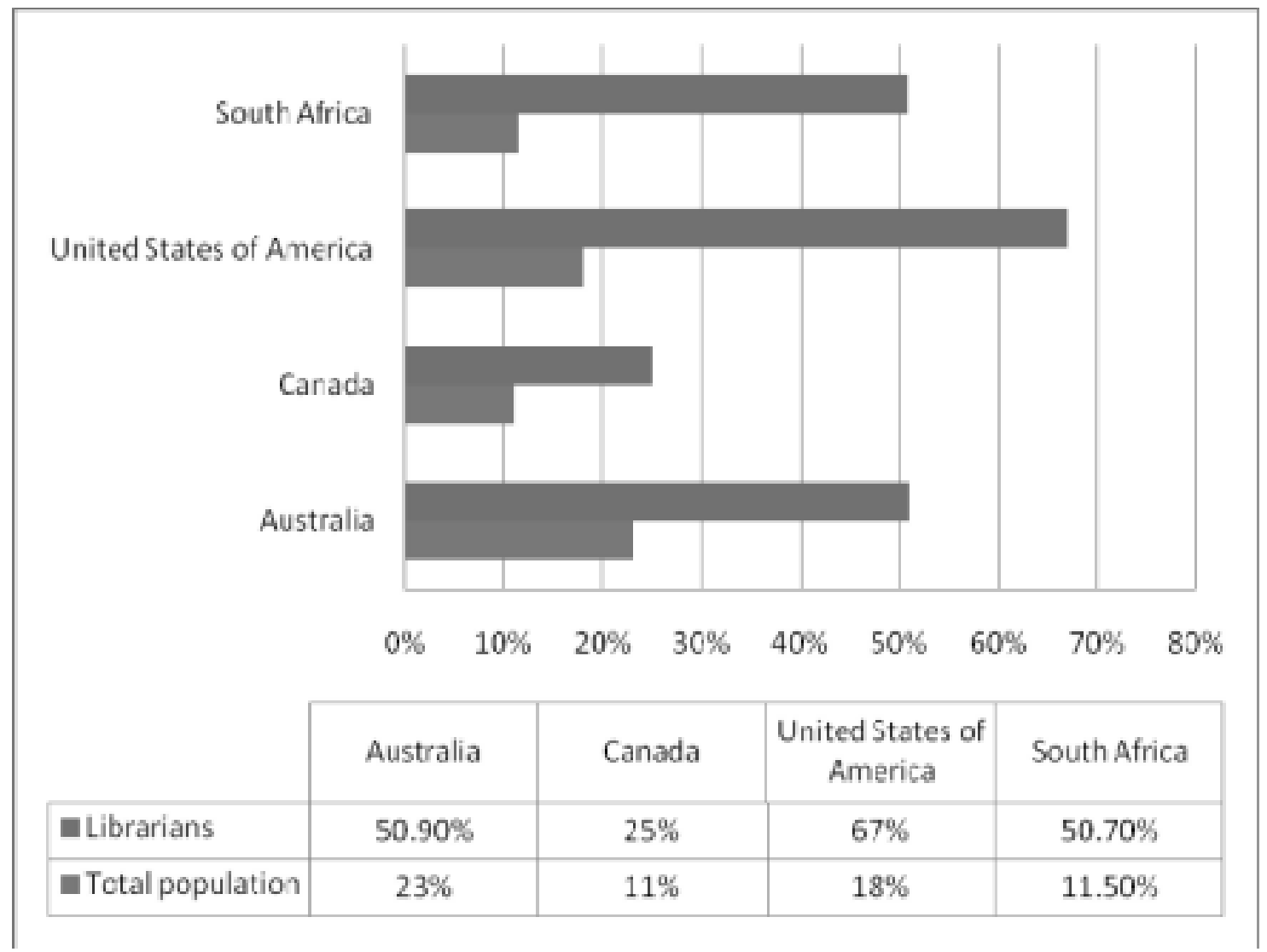

Figure 3 Updated comparison of population retiring versus librarians retiring per country

After updating Figure I with the data collected in this study, Figure 3 above compares the sections of the retiring populations of South Africa, the United States of America, Canada and Australia with the countries' retiring librarian populations. With the data added, Figure 3 illustrates that half of the South African academic librarians will be retiring within the next 10 to 15 years; this is more than four times the average of $11.5 \%$ of the total South African population. Considering these research findings South African academic libraries do indeed face an imminent staff exodus and need to establish planning and training programmes for new middle and top management positions for succession planning.

\section{Possible implications and forewarning for South African academic libraries}

While it is imperative for organisations to develop and execute diversity policies, focusing on every individual's diversity will render the concept futile. Most organisations prefer to focus their attention on race, gender and sexual preferences and this focus is reflected in government legislation and company charters. However, being aware of age diversity in an organisation can present many benefits and advantages to organisations, chief of which is increased productivity due to workplace cohesion and job satisfaction amid a work environment borne from change.

The changes to HEl have also led academic libraries to incorporate diversity as they have a responsibility to support multiculturalism and to create and manage a diverse workforce that is sensitive to differences and respects pluralism. For academic libraries to attract a diverse workforce and specifically an age diverse workforce, it is important to ascertain the age profile of staff in order to formulate and implement succession planning policies and staff retention policies.

From the literature review it became clear that investigation into the age diversity of South African academic libraries is lacking. This does not imply that generational studies are lacking. Evidently, numerous international and local studies have been undertaken to investigate different generations of library patrons and the implications of age diversity impacting on the client-librarian relationship. However, very few studies focus on the different generations of librarians as co-workers and how age diversity affects, for example, co-worker relationships, library management, retention strategy and succession planning. Therefore, generational aware strategies to retain and attract staff need to be found if academic libraries are to thrive in a diverse work environment. 
Finally, in a diverse work environment, age is a factor to be reckoned with. It is therefore suggested that further research be done, not only on age diversity per se, but with specific emphasis being given to how the different ethnic cultures existing within the South African academic library arena influence generational diversity. This will aid library management in sustaining workplace cohesion.

\section{Conclusion}

With half of the South African academic librarians retiring within the next 10 to 15 years, which is more than four times the national average, an imminent staff exodus will soon be on hand. The management of academic libraries are therefore advised to take cognisance of the fact that their staff complement will, in all likelihood, be reduced by half in the near future. It is of high importance for library management to consider their organisations' age diversity and to develop appropriate recruitment actions and implement succession policies. As most of the middle and senior level management positions are currently filled by those retiring in the next 15 to 20 years, the planning and training of new middle and top management staff members must form part of succession planning policies in order to avoid a leadership vacuum.

\section{References}

Aghazadeh, S-M. 2004. Managing workforce diversity as an essential resource for improving organizational performance. International Journal of Productivity and Performance Management, 53(5/6):521-531.

Andrews, D., Nonnecke, B. \& Preece, J. 2003. Electronic survey methodology: a case study in reaching hard-to-involve Internet users. International Journal of Human-Computer Interaction, 16(2):85-2 I0.

Awbrey, S.M. 2007. The dynamics of vertical and horizontal diversity in organization and society. Human Resource Development Review, 6(I):7-32.

Barnard, Z. 2008. Online community portals for enhanced alumni networking. Doctoral Thesis. Johannesburg: University of Johannesburg.

Bell, M.P. 2007. Diversity in organizations. Mason: Thomson South-Western.

Bopape, S. 2005. Management development needs of library managers belonging to Gauteng Environs Library and Information Consortia (GAELIC) in South Africa. South African Journal of Libraries and Information Science, 7I ( I):64-73.

Brindley, L. 2006. Re-defining the library. Library Hi-Tech, 24(4):484-495.

Canadian Library Association. 2003. Canadian library human resource study. [Online]. http://www.cla.com. Accessed 22 September 2008.

Canadian Library Association. 2005. The future of human resources in Canadian libraries. [Online]. http://www.cla.com. Accessed 22 September 2008.

Cilliers, F. \& Smit, S. 2006. A systems psychodynamic interpretation of South African diversity dynamics: a comparative study. South African Journal of Labour Relations, 30(2):5-18.

Clements, P. \& Jones, J. 2002. The diversity training handbook: a practical guide to understanding and changing attitudes. London: Kogan Page.

Datamonitor. 2009. South Africa: Mid-year population by age. [Online]. http://0-dbl.datamonitor.com.ujlink.uj.ac.za/countrystats/ViewResults.aspx. Accessed 23 February 2009.

De Ferreire Kemp, F. 2007. Leadership and diversity: constant companions, understanding differences begets productivity. Industrial Engineer, May:40-43.

Desmette, D. \& Gaillard, M. 2008. When a worker becomes an older worker: the effects of age-related social identity on attitudes towards retirement and work. Career Development International, I3(2): I 68- I 85.

Dewey, B. \& Keally, J. 2008. Recruiting for diversity: Strategies for twenty-first century research librarianship. Library Hi-Tech, 26(4):622-629.

Dinwoodie, D.L. 2005. Solving the dilemma: A leader's guide to managing diversity. Leadership in Action, 25(2):3-6.

Dombai, C. \& Verwey, S. (1999). The impact of organisational culture as a context of interpersonal meaning on the management of organisational diversity. Communicare, I8(2): I04- I3I.

Goldman, G.A. \& Van Tonder, C. 2006. The University of Johannesburg merger: academics experience of the pre-merger phase. Acta Commercii, 6:147-I6I.

Greer, C.R. \& Virick, M. 2008. Diverse succession planning: Lessons from the industry leaders. Human Resource Management, 47(2):35I-367.

Greybe, L. \& Uys, F.M. 200I. Strategies for diversity management. Journal of Public Administration, 36(3): I85-20I.

Hall, M., Symes, A. \& Luescher, T. 2004. The governance of merger in South African higher education: Research report prepared for the Council on Higher Education. [Online]. http://www.che.ac.za/documents/d000072/. Accessed 2 September 2008.

Hallam, G. \& Lee, J. 2008. neXus: An investigation into the LIS workforce in Australia. Australian Library and Information Association. [Online]. http://www.alia.org.au/employment/workforce/NeXus\%20StageOne\%20Australia\%20Final.pdf. Accessed 22 September 2008.

Human, L. 2005. Diversity management: For business success. Pretoria: Van Schaik.

Kagan, A. 2003. The transformation of South African librarianship: survey results and analysis of current opinions. Progressive Librarian, 22:I.

Kaplowitz, M.D., Hadlock, T.D. \& Levine, R. 2004. A comparison of web and mail survey response rates. Public Opinion Quarterly, 68(I):94-101.

Kreitz, P.A. 2008. Best practices for managing organizational diversity. The Journal of Academic Librarianship, 34(2): I0I - I 20.

SA Jnl Libs \& Info Sci 2010, 76(I) 
Lynch, M.J., Tordella, S. \& Godfrey, T. 2005. Retirement and recruitment: a deeper look. American Libraries, $36(\mathrm{I}): 28$.

Maree, K. 2007. First steps in research. Pretoria: Van Schaik.

Maurer, T.J., Barbeite, F.G., Weiss, E.M. \& Lippstreu, M. 2008. New measures of stereotypical beliefs about older workers' ability and desire for development: exploration among employees age 40 and over. Journal of Managerial Psychology, 23(4):395-4I8.

McCarthy, J. 2005. Planning a future workforce: an Australian perspective. New Review of Academic Librarianship, I I ( I):42-56.

Mosley, P.A. \& Kaspar, W.A. 2008. Making the good hire: updating hiring practices for the contemporary multigenerational workforce, part one. Library Administration and Management, 22(2):92-99.

National Council for the Library and Information Services. 2008. Library and Information Services Transformation Charter. [Online]. http://www.liasa.org.za/conferences/conference2008/LIASA_Library_Transformation_Charter_Report.pdf. Accessed 30 September 2008.

National Council for the Library and Information Services. 2008. Library and Information Services Transformation Charter. [Online]. http://www.liasa.org.za/conferences/conference2008/LIASA_Library_Transformation_Charter_Report.pdf. Accessed 30 September 2008.

Nel, H. \& Stumpf, R. 2007. Reflecting on the experience of the merger at the Nelson Mandela Metropolitan University: successes and challenges. Discourse, $35(\mathrm{I}): \mathrm{I}-10$.

Ngulube, P., Mokwatlo, K. \& Ndwandwe, S. 2009. Utilisation and prevalence of mixed methods research in library and information research in South Africa 2002-2008. South African Journal of Library \& Information Science, 75(2): I05-I I6.

Nixon, J.M. 2008. Growing your own leaders: Succession planning in libraries. Journal of Business and Finance Leadership, I3(3):249-360.

Nkoane, M.M. 2006. Challenges facing South Africa's educational advancement. International Journal of Education Advancement, 6(3):243-252.

Perry, E.L., Kulik, C.T. \& Zhou, J. 1999. A closer look at the effects of subordinate-supervisor age differences. Journal of Organizational Behavior, 20(3):34I-357.

Punch, K.F. 2003. Survey research: the basics. London: SAGE.

Raubenheimer, J. \& Müller, H. 2006. Rethinking leadership roles for the academic library: the attitudes of library staff towards a leadership-driven academic information service enterprise. Mousaion, 24(2):232-248.

Royse, M., Conner, T. \& Miller, T. 2006. Charting a course for diversity: an experience in climate assessment. Portal: Libraries and the Academy, 6(I):23-45.

Saw, G. \& Todd, H. 2007. Library 3.0: where art our skills? World Library and Information Congress: 73rd IFLA General Conference and Council, 19-23 August 2007, Durban, South Africa. Online]. http://www.ifla.org/iv/ifla73/index.htm. Accessed I 8 July 2009.

Sayed, Y. 2000. The governance of the South African higher education system: balancing state control and state supervision in co-operative governance? International Journal of Educational Development, 20:475-489.

Sayers, R.M. 2007. The right staff from X to Y: Generational change and professional development in future academic libraries. Library Management, 28(8/9):474-487.

South African Yearbook 2008/2009. 2009. [Online]. http://www.gcis.gov.za/resource_centre/sa_info/yearbook/2008-09.htm. Accessed 18 July 2009.

StatsSA. 2007. Mid-year population estimates. Statistical release: P0302. Pretoria: Statistics South Africa.

Thomas, G. \& Fourie, I. 2006. Academic library consortia in South Africa: where we come from and where we are heading? The Journal of Academic Librarianship, 32(4):432-438.

Van der Walt, S. 2010. Generational awareness in co-worker relationships in the interactive information society. Masters Thesis. Johannesburg: University of Johannesburg.

Wilder, S. 1996. Generational change and the niche for librarians. The Journal of Academic Librarianship, 22(5):385-386. 